\title{
Styl zakopiański Stanisława Witkiewicza i jego differentia specifica
}

\section{Stanisław Witkiewicz's Zakopane style and its differentia specifica}

\section{Streszczenie}

Praca jest próbą zrekonstruowania metody twórczej Stanisława Witkiewicza dokonaną na podstawie jego pism rozproszonych. Styl zakopiański stał się fenomenem w szerokim spektrum polskich stylów narodowych. Inspiracją dla klasycznych stylów narodowych na ogół był arbitralnie dobrany zbiór form zaczerpniętych z określonego stylu historycznego związanego z danym narodem bądź państwem. Często był to zbiór eklektyczny. Stanisław Witkiewicz konsekwentnie unikał zapożyczeń i wtórności, wykorzystując wyłącznie inspiracje z ludowej sztuki Podhala. W metodologii jego architektury elementy o charakterze „,racjonalnym”, jak: postulat funkcjonalnego rozplanowania pomieszczeń, propagowanie prawidłowego nasłonecznienia wnętrz oraz utrzymywania ich czystości, a także eksponowanie konstrukcji budynków, przeplatały się z elementami o charakterze "romantycznym", jak np.: wprowadzanie ornamentyki, głównie o tematyce roślinnej, oraz kreowanie warstwy symbolicznej architektury, przesyconej pierwiastkami swoistej mitologii.

Słowa kluczowe: styl narodowy w architekturze, styl zakopiański, sztuka ludowa, architektura ludowa, Podhale

\section{Abstract}

The work is an attempt to reconstruct the creative method of Stanisław Witkiewicz based on his various written works. The Zakopane style has become a phenomenon within a wide spectrum of Polish national styles. The inspiration for classic national styles was generally an arbitrarily selected set of forms taken from a specific historical style associated with a given nation or state. It was often an eclectic collection. Stanisław Witkiewicz consistently avoided borrowing and repetitions, using only inspirations from the folk art of Podhale. In the methodology of his architecture, 'rational' elements were interspersed with ornaments mainly on the subject of plants and elements of a mythology.

Keywords: national style in architecture, Zakopane style, folk art, folk architecture, Podhale 


\section{APOTEOZA NARODU CZY LUDU? U ŹRÓDEŁ STYLU ZAKOPIAŃSKIEGO}

Geneza stylu narodowego zakopiańskiego w sposób zasadniczy różni się od genezy klasycznych stylów narodowych. Źródłem inspiracji pozostałych stylów narodowych były formy architektoniczne związane z określonymi stylami historycznymi. Tworzono na ogół w sposób arbitralny określony katalog wybranych form i definiowano zasady ich zestawiania. Dopuszczano w pewnej mierze do eklektyzmu - zapożyczania form z innych stylów (np. Jan Sas-Zubrzycki prócz zasadniczych dla stylu nadwiślańskiego form gotyckich stosował w dolnych częściach swoich kościołów również elementy stylu romańskiego; Franz Schwechten stosował formy bizantyńskie we wnętrzach Zamku Cesarskiego). W sposób arbitralny definiowano również "narodowy” charakter owych stylów.

Idea stylów narodowych z perspektywy upływu czasu okazała się ideą kontrowersyjną. Tezy formułowane przez jej twórców wydają się dzisiaj enigmatyczne, niektóre nie wytrzymały próby czasu. Do upadku idei stylów narodowych w znacznym stopniu przyczyniła się właśnie zasada arbitralnego wyboru form historycznych.

Stanisław Witkiewicz wykreował styl zakopiański jako narodowy, odwołując się do form architektonicznych budownictwa ludowego polskiego Podhala. Podczas długoletniego procesu współpracował z miejscowymi góralami, badaczami i artystami. Metodologia kreacji stylu stosowana przez architekta była kompleksowa, logiczna i konsekwentna. Nie było w niej miejsca na arbitralność wyborów. Dokonywane przez architekta wybory form, układów odniesienia miały zawsze udowodniony rodowód pochodzenia od miejscowych form architektury ludowej. Wszystkie rozwiązania były weryfikowane poprzez praktykę budowlaną, a opisy wykonywane w zasadzie ex post, po wykonaniu.

Dążenie Witkiewicza do czystego i purystycznego wywiedzenia form wyłącznie z architektury podhalańskiej można udowodnić, porównując jego metodę twórczą z metodą Dušana Jurkoviča, architekta słowackiego działającego po drugiej stronie Tatr.

Jurkovič tworzył własny styl oparty na architekturze ludowej słowackiej, nie miał jednak ambicji kreowania stylu narodowego. Architekt w swojej twórczości łączył pierwiastki sztuki ludowej z elementami secesji wiedeńskiej i wzorami angielskimi. Integracja tych elementów widoczna jest zwłaszcza w projekcie jego domu własnego w Brnie Žabovřeskach, zwanego „Domem pod Wzgórzem” (1905-1906). W wilii architekta odbywały się wystawy architektury i sztuki użytkowej. Nawiązania do Art Nouveau występowały również w innych obiektach słowackiego architekta: w zespole schronisk turystycznych na grzbiecie Pustevny pod Radhošt́em (1897-1899), w projekcie Drogi Krzyżowej na górze Hostyn koło Ołomuńca (1903), w domu regionalnym w Skalicy (1905), w willi „U Rezku” (1900-1901). Witkiewicz zdecydowanie odżegnywał się od zapożyczeń z architektury prezentującej inne kierunki bądź wywodzącej się z innych krajów.

Artysta w tekstach rozrzuconych w swoich pismach dążył do wyjaśnienia wyboru sztuki ludowej Podhala jako układu odniesienia i źródła inspiracji tworzonej przez siebie 
architektury. Architektura ta początkowo miała być miejscowym stylem funkcjonalnego, komfortowego i higienicznego budownictwa dla turystów i kuracjuszy. Dalekosiężnym celem stała się kreacja polskiego stylu narodowego.

\section{METODOLOGIA KREACJI STYLU ZAKOPIAŃSKIEGO WITKIEWICZA ZREKONSTRUOWANA NA PODSTAWIE JEGO PISM ROZPROSZONYCH}

Witkiewicz nigdzie nie opisał w sposób całościowy swojej metodologii. Można jednak zrekonstruować tok myślenia architekta z poszczególnych pism rozproszonych. Warto je prześledzić, są one napisane charakterystycznym stylem, oddającym klimat entuzjazmu, z jakim tworzono ówczesną architekturę. Dlatego w artykule zamieszczono obszerne cytaty pochodzące z jego dzieł.

Zrekonstruowany wywód rozpocząłby się od udowodnienia trafności wyboru przez Witkiewicza ludowej architektury Podhala jako układu odniesienia i źródła inspiracji. Ów opis architektury góralskiej jako źródła inspiracji jest poprzedzony poetycką charakterystyką ludu góralskiego. W dziele Na przełęczy. Wrażenia i obrazy z Tatr opisuje Witkiewicz wyjątkowość ludu górali podhalańskich. Owa wyjątkowość wywodzi się według niego z dwóch cech. Pierwszym czynnikiem decydującym o ich rzadkich zaletach jest ciągły kontakt z dziką, tatrzańską przyrodą. Po drugie: górale zawsze byli ludźmi wolnymi, nigdy nie byli chłopami pańszczyźnianymi. We wspomnianej opowieści Na przełęczy... pisze Witkiewicz: „Chłop ten przytem nie był niczyim poddanym. Rósł wolny i dziki, i przy wszystkich formach uniżoności, zachowywał godność osobistą i hardość ducha. Szanował się i kazał siebie szanować, śpiewając tym, którzy mu chcieli imponować pańszczyźnianemi narowami: Panowie, panowie, będziecie panami, / Ale nie będziecie przewodzić nad nami”. Zresztą, czasy powstawania popularności górali przypadały na chwilę żywego rozbudzenia pojęć demokratycznych. „»'Zbliżać się do ludu « zaczynało być w ogóle w modzie; cóż mówić o zbliżaniu się do ludu, którego umysłowe i towarzyskie przymioty, którego życie i postać były tak oryginalne, tak różne od zjawisk pospolitych, codziennych; ludu, który był częścią wspaniałej natury, [...] ludem, który miał w ogóle mnóstwo pysznych rasowych przymiotów"1.

Opis Witkiewicza ma charakter prozy poetyckiej, w niektórych miejscach zbliża się do panegiryku na cześć górali. Sporo miejsca poświęca pisarz relacjom pomiędzy góralami i przybyszami. Panowała wówczas atmosfera wzajemnej fascynacji pomiędzy obydwoma bardzo różniącymi się wtedy grupami społecznymi. W innym miejscu opowieści opisuje legendarne postacie góralskich zbójników. Stanowią one kwintesencję cech mieszkańców gór - ich odwagi i umiejętności radzenia sobie z przyrodą.

Architektura tworzona przez lud o wyjątkowych przymiotach powinna mieć również wyjątkowe cechy. Chata góralska jest według Witkiewicza archetypem budynku mieszkalnego. O jej ponadczasowych zaletach decydują: prostota i funkcjonalność, ogólne proporcje oraz 
góralskie zdobnictwo. Wyposażenie chaty góralskiej stanowiło jedność stylistyczną z budynkiem. Motywy zdobnictwa pokrywały elementy budowlane, całe chaty oraz meble i sprzęty. Wyjątkowe cechy chaty opisuje Witkiewicz w opowieści Na przełęczy... w następujący sposób:

Chata góralska od pierwszego spojrzenia wydaje się czemś pełnem charakteru - tego pierwiastka osobowości, który wyróżnia z tłumu, ludzi szczególnych i rzeczy niezwykłe.

Sam szkielet budowy to pudło, w którem się chowa człowiek, ta część każdej rzeczy, która służy do celów praktycznych, jest równie prawie prosta i niezłożona jak w każdej innej chacie. Cztery ściany, dwa szczyty, dwie pochyłe płaszczyzny dachu, z małem zboczeniem od symetrii na jednę stronę, pod którq mieszczq się dodatkowe izby - oto cala chałupa.

Lecz na wszystkich jej częściach leży piętno pewnego stylu, pewnego motywu linii. Od zacięcia belki do ostrego szczytu, od pazdura do ornamentów rżniętych wewnq̨trz, wszystko prawie ma ten sam charakter linii przecinających się pod dość ostrym kq̨em².

W ówczesnej góralskiej chacie przeważały przestrzenie ciemne, prawie pozbawione światła, w których panował nieporządek i chaos. Jednak głównym pomieszczeniem była tzw. biała izba - pełniąca rolę salonu. Górale dbali o tę izbę, była ona zapełniona pamiątkami i obrazami. Witkiewicz rozwijając ideę stylu zakopiańskiego, uczynił z białej izby swoisty wzorzec nowoczesnego, higienicznego mieszkania. W swojej metodologii stosował zasadę maksymalnego zachowania wartości architektury ludowej Podhala, jednak eliminował elementy chaotyczne i niehigieniczne. Wysoką ocenę białej izby zawarł Witkiewicz w następujących słowach:

Izba na prawo, świetlica, albo biała izba, jest to salon góralski. [...] Cala jedna ściana zawieszona obrazami, strasznemi, lecz oryginalnymi obrazami, malowanemi na szkle, które swojq ponurościq i naiwnościq wyróżniajq się od krzyczqcej lichoty niemieckich litografii, z któremi sq̨siadujq. [...] Izba biała, prawie bez zmiany, może być przeniesiona do bardzo nawet wykwintnych i bogatych mieszkań i stanowić przepysznq salę jadalnq ${ }^{3}$.

Stanisław Witkiewicz w sposób bardziej szczegółowy opisuje inspiracje i zasady stylu zakopiańskiego w Pismach tatrzańskich I w rozdziale Styl zakopiański. Zeszyt II Dom. Przedstawia swoje poszukiwania źródła inspiracji dla stylu narodowego. Miała być to architektura, która nie byłaby wtórna i nie powinna być związana z wpływami sztuki obcych narodów. Odrzuca w związku z tymi założeniami Witkiewicz architekturę starych dworów polskich jako wzorzec polskiego stylu w budownictwie. Uważa, że w ich wyrazie formalnym było zbyt wiele zapożyczeń z obcej architektury. Należy w tym miejscu wyraźnie zaznaczyć, że Witkiewicz nie potępia wpływów obcej sztuki w polskich budowlach, nie chce tylko, by takie wpływy były widoczne w architekturze mającej być źródłem inspiracji dla stylu narodowego. Z drugiej strony eliminuje Witkiewicz obiekty architektury ludowej poza architekturą podhalańską. Są one niewątpliwie związane z kulturą polską, ale mają według niego za mało walorów kompozycyjnych, by stać się elementem inspirującym dla stylu narodowego. Architektura ludowa Podhala pozostaje w bliskich związkach z kulturą polską, pozostając ze względu na górskie otoczenie w pewnej izolacji od obcych wpływów. Drugim czynnikiem predestynującym 
ją do stania się elementem źródłowym stylu narodowego są jej związki z pierwotną naturą. Trzecim czynnikiem jest wysoki poziom technologiczny i kompozycyjny tej architektury. Wszystkie te trzy czynniki sprawiają, że jedynie architektura ludowa wywodząca się z Podhala ma w sobie potencjalne właściwości by stać się siłą inspirującą przy tworzeniu stylu narodowego polskiego. Przytoczmy w tym miejscu słowa samego Stanisława Witkiewicza:

Gdzież więc jest źródło polskiego stylu w budownictwie, jeżeli ten styl nie jest i nie będzie wytworem indywidualnej twórczości, jeżeli ma się rozwijać z już istniejq̨cych pierwiastków architektonicznych? [...] Jeżeli form tych nie znajdziemy w starym dworze, jeżeli zwrócimy się po nie do chaty, to czy chata z dolin ze swojq słomianq strzechq i formami konstrukcyjnymi, zamazanymi glinq i zalanymi wapnem, może być punktem wyjścia dla stylu polskiego w budownictwie? Z trudnościq. Chata zaś podhalańska ma w sobie pierwiastki konstrukcyjne i zdobnicze wyższego typu, które $w$ dodatku były rozpowszechnione w całej Polsce drewnianej, a z jej kulturq przechodziły na ziemie sqsiednie. Chata ta ma wspólne cechy z budownictwem czeskim na Morawach, ale typ ten ginie tam, gdzie się zaczyna rdzennie niemiecka kultura. Czyli jest to budownictwo zachodniosłowiańskie, które na wschód sięga tak daleko, jak sięgajq wpływy polskiej kultury, rozwijajq̨ wiec ten pierwiastek budowniczy możemy być pewni, że idziemy od źródła rzeczywiście polskiego dawnego budownictwa, gdy tymczasem wychodzq̨c ze "starego dworu i lamusa", możemy Polskę ubrać w styl francusko-niemiecki lub też pokryć jq płaskim filisterstwem stylu biedermaier'.

W Pismach Tatrzańskich I opisuje Witkiewicz proces kształtowania stylu zakopiańskiego poprzez realizację kolejnych willi i domów. Podstawą owego procesu były modyfikacje wzorca chaty podhalańskiej. Zmierzały one w kierunku kreacji architektury funkcjonalnej, higienicznej i komfortowej. Wykorzystywano w tym celu, jak wspomniano, wzór części reprezentacyjnej chaty zwanej białą izbą. Witkiewicz starał się udowodnić ludowe, góralskie pochodzenie dokonywanych przez siebie modyfikacji. Opisując budowę willi „Koliba” dla Zygmunta Gnatowskiego, podkreśla wszechstronność inspiracji wychodzących od strony wzorca chaty góralskiej: „Wszystkie zaś pierwiastki budownicze, konstrukcyjne czy zdobnicze znalazły się albo w stanie zupełnie rozwiniętym do miary wyższych wymagań, albo też w formach zaczątkowych, w budownictwie ludowym. Od fundamentów do szczytu, na wszystko, czego potrzebował dom, znalazło się materiał w chałupie" ${ }^{\prime}$.

Bardzo istotnym elementem dla architektury stylu zakopiańskiego było ukształtowanie dachu. Poddasze musiało pomieścić dodatkowe pomieszczenia mieszkalne. Wymagało to modyfikacji formy dachu i jego konstrukcji. Jednak zasadniczy kształt z charakterystycznymi stromymi spadkami pozostał. Spośród modyfikacji dachu należy wymienić: wyględy, które szczegółowo zostaną omówione poniżej; werandy; werandy przeszklone, tzw. pajty; przyłapy (ganki przykryte wysuniętym okapem, najpiękniejszy w wilii „Pod Jedlami”), szczyty dachowe z balkonem (pierwszy raz zastosowany w willi „Pepita”). Jednak zasadniczy kształt z charakterystycznymi stromymi spadkami pozostał. Według Stanisława Witkiewicza dach chaty góralskiej był archetypem dachu polskiego. Pisze o szczególnych cechach dachu zakopiańskiego architekt w następujących słowach: 
Dach zakopiański nie jest dachem górskim - jest dachem polskim, tak samo, jak całe to budownictwo, które panowało niegdyś na całym obszarze Polski. Proporcje i forma tego dachu wynikaja z potrzeby nadania mu mocy przeciw naporowi wiatru, siły do dźwigania śnieżnego nasypu i spadku do szybkiego spłynięcia wody deszczowej. Może być, że górale wobec warunków klimatycznych Pod hala bardziej go wzmocnili, że kierowani swoim poczuciem piękna kształty jego udoskonalili, lecz zasadniczo dach ten nie jest wyłącznq właściwościq Podtatrza

Podczas licznych prowadzonych budów i w trakcie rozważań teoretycznych pojawiła się konieczność ukształtowania nowych elementów, nieistniejących w chłopskiej chacie. Architekt pragnął, by nawet owe całkowicie nowe elementy związane były z tradycją podhalańską. Przykładem takiego postępowania jest kreacja słynnych wyględów. Witkiewicz zaadaptował wzór prymitywnego urządzenia techniczno-gospodarskiego - swego rodzaju klapy w dachu służącej do wyrzucania siana. Urządzenie to zainspirowało architekta do stworzenia pulpitowych otwarć wystających z połaci dachowych. Wyględy umożliwiły znaczące poszerzenie kubatury użytkowej w poddaszach w porównaniu z tradycyjnymi lukarnami. Lukarny kryte dachami dwuspadowymi mają ograniczoną szerokość, dobudówki pokryte dachami pulpitowymi, jak wyglądy, mogą być zdecydowanie szersze. Boczne ścianki wyględów ozdobione były promienistym ornamentem nawiązującym do archetypicznego góralskiego "słonecka”. Z drugiej strony ów promienisty ornament można odczytywać jako metaforę zastygniętego ruchu pierwowzoru wyględu - otwierającej się klapy w dachu. Jako dodatkowe uzasadnienie dla formy wyględów i jej związków z kulturą ludową Podhala opisuje Witkiewicz fakt pierwszego, bardzo prymitywnego przystosowania klapy dachowej do celów mieszkalnych przez jednego z górali zakopiańskich. Wyględ wybudowano po raz pierwszy według projektu Stanisława Witkiewicza w willi „Koliba” (1892-93). Architekt w następujący sposób opisuje genezę i zalety tego detalu architektonicznego:

W dachu zakopiańskim oprócz dymników wprowadziliśmy wyględy. Górale w dachach szop majq część, dajq̨ca się podnieść na dragu dla wyrzucenia siana lub słomy. Tym kierowany, jeden gazda przy ulicy Kościeliskiej, chcąc w dużym poddaszu umieścić pokój mieszkalny, odchylit część dachu do góry i wpuścił światło, a zarazem utworzył rodzaj loży, balkonu, osłoniętego od słońca, deszczu i wiatru. Wzięliśmy ten motyw i po nadaniu mu bardziej wyrobionego kształtu, wprowadziliśmy do nowych domów, przede wszystkim do Koliby, w której wszystkie prawie pierwiastki zakopiańskiego budownictwa zostały wypróbowane i zastosowane do nowych warunków. Wyględ jako udogodnienie mieszkania jest nabytkiem nadzwyczajnym. Powiększa on je przez to, że $w$ dnie pogodne i ciepłe staje się jeszcze jednym pokojem, pełnym powietrza, i w okolicy takiej, gdzie ciqgle jest na co patrzeć, dajqcym możliwość patrzenia; służy jako wyborne miejsce werandowania dla chorych, jako miejsce odpoczynku dla słabych, jako miejsce do ustawienia roślin i kwiatów ${ }^{7}$.

Jedną z cech charakterystycznych stylu zakopiańskiego jest formowanie stosunkowo wysokich kondygnacji przyziemia omurowanych łamanym kamieniem bądź otoczakami. Dzięki w taki sposób uformowanemu przyziemiu można było w wydatny sposób zwiększyć kubaturę całego budynku, zachowując proporcje właściwe dla willi. Również i w tym przypadku 
Witkiewicz stara się wywieść genezę wysokich, kamiennych podmurówek z architektury ludowej. Powołuje się na przykład chat na Gubałówce:

Stawianie też ganków, werand, galerii biegnqacych dokoła domu na łukach kamiennych zostało również dopatrzone w chatach na zboczu Gubałówki i dało w rezultacie pierwiastki malownicze, a zgodnie z tym charakterem całości budowy, w której więźba tak jawnie występuje na przód, tak rzuca się w oczy i stanowi jedna z części składowych wrażenia piękna zakopiańskiego domu.

Fundamentalną cechą stylu zakopiańskiego stało się nasycenie architektury formami ornamentalnymi. Był to jeden z przejawów intensyfikacji treści symbolicznych - zjawiska typowego dla stylów narodowych. W przypadku stylu zakopiańskiego motywy zdobnicze pokrywały przede wszystkim meble i sprzęty (m.in. słynne łyżniki). Posługiwano się w przeważającej części motywami roślinnymi. Witkiewicz stosując ornamentykę góralską, korzystał ze słynnych tablic litograficznych zamieszczonych w dziele Budownictwo ludowe na Podhalu autorstwa Władysława Matlakowskiego. Książka ukazała się w roku 1892 nakładem Akademii Umiejętności w Krakowie. Należy zwrócić uwagę na fakt, że również ubiory góralskie wzbogacone były ornamentami. Dzięki zdobnictwu stworzono w stylu zakopiańskim jednorodną przestrzeń stylistyczną integrującą architekturę, wzornictwo i wystrój wnętrz.

Ornamentyka stała się również elementem budowy koncepcji stylu zakopiańskiego jako stylu narodowego. Witkiewicz pragnął rozszerzyć spektrum motywów roślinnych, tradycyjnie ograniczone do roślin tatrzańskich, o motywy roślinne z innych części Polski. Pisze o tym architekt, charakteryzując ornamentykę wprowadzoną w willi „Koliba”:

Poręcze od schodów, werand, balkonów, przepasanie, jak w Kolibie, piętra ozdobnq smugq, wszystko to sq miejsca, na których rozsypujq się motywy z przezroczy łyżników, przeróżne gwiazdy, parzenice, krzyżyki, leluje, gadziki, krokiewki, mirwy lub zwijajq się duże plastyczne gałęzie stylizowanych lelui. Tę ornamentykę ludowq wzbogaciliśmy kilku motywami tatrzańskich roślin, jak złotogłów, karlina, paproć i kilku innych kwiatów, których bogactwo w Tatrach może dostarczyć niejednego jeszcze pierwiastku formy. To, że budujq̨c z poczq̨tku pod Tatrami, użyliśmy roślin tatrzańskich, nie przesqdza bynajmniej możności dalszego rozwijania tej ornamentyki przez wprowadzenie roślin właściwych nizinom, ponieważ samo to budownictwo, zwane stylem zakopiańskim, nie jest bynajmniej przeznaczone wyłącznie dla Podhala i nie na Podhalu powstało?.

Tendencja do integracji sztuk była zjawiskiem charakterystycznym dla ówczesnych prądów artystycznych, przede wszystkim dla secesji. Warto zauważyć, że w sztuce początku XX wieku wkrótce miało dojść do przełomu - wyłonienia się przeciwstawnej tendencji, do eliminacji ornamentu. W roku 1908 Adolf Loos opublikował swój słynny esej Ornament i zbrodnia. Fundamentalny dla sztuki początku XX wieku spór na temat roli ornamentu odzwierciedlił się w pismach i twórczości architektonicznej Stanisława Witkiewicza. Zbliżone do secesji stanowisko dążenia do maksymalnego nasycenia ornamentem architektury próbował pogodzić ze stanowiskiem zdecydowanego uwydatniania konstrukcji obiektu. Uważał, że rolą ornamentu powinno być akcentowanie konstrukcji. Taką zasadę starał się wprowadzać 
w swoich budowlach realizowanych w stylu zakopiańskim. Wyjaśniał tę zasadę w swoich Pismach Tatrzańskich. Jest to jeden z piękniejszych opisów stylu zakopiańskiego:

Zasadniczq cechq stylu zakopiańskiego jest konstrukcyjność - jest jawność więźby i dqż̇ność do jej podkreślenia za pomoca ornamentyki. Kto nie ma zmysłu konstrukcyjnego, kto nie czuje ducha tej walki z bezwładem materii, walki z siłq ciq̨żenia, którq jest każda konstrukcja, ten nie może tworzyć z materiału form, jaki nam dała sztuka ludowa. Innq cechq stylu za kopiańskiego, wynikajqca z zastosowania konstrukcyjności do materiału drzewnego, jest jego charakter prostolinijny i prostokqqtny - z bardzo rzadkimi odstępstwami od tej zasadniczej, znamiennej formy ${ }^{10}$.

Stanisław Witkiewicz w zasadzie nie zajmował się polityką ani szeroko pojętymi kwestiami społecznymi. Stworzona przez niego w ramach stylu zakopiańskiego architektura w jakimś sensie mogła być odbierana jako manifest łączności czy też wspólnoty różnych klas społecznych. Takie rozumienie zgodne jest z zasadami solidaryzmu przypisywanego Witkiewiczowi. Solidaryzm według Nowej Encyklopedii PWN to „kierunek społeczno-polityczny, głoszący tezę o naturalnej wspólnocie interesów, łączącej ludzi niezależnie od miejsca zajmowanego przez nich w strukturze społecznej [...]"11. Stanisław Witkiewicz definiuje misję społeczną stylu zakopiańskiego: „Ideałem społecznym każdego pierwiastka kultury jest ogarnięcie przezeń całego społeczeństwa, jest nadanie wspólnych cech cywilizacyjnych wszystkim społecznym warstwom, jest wytworzenie idealnych łączników między duszami, ponad przepaściami strasznych materialnych nierówności i przeciwieństw. Styl zakopiański spełnił to zadanie"12. Wydaje się, że to stwierdzenia dotyczy jedynie warstwy wizualnej architektury stylu zakopiańskiego. Poprzez nobilitację tradycyjnej chaty nobilitowała ona również prosty lud góralski. Witkiewicz nigdy nie podjął wyzwania tworzenia autentycznej architektury socjalnej.

Zestawiając w formie bardzo skrótowej podstawowe cechy stylu zakopiańskiego i jego metodologii (poniżej), można zauważyć racjonalne podstawy tego stylu. Racjonalność ta moim zdaniem wyróżniała ten styl z szerokiego spektrum innych stylów narodowych.

1. Właściwa twórczość architektoniczna została poprzedzona wnikliwymi studiami i analizami etnograficznymi - poświęconymi badaniom ludności góralskiej oraz analizom architektury ludowej Podtatrza.

2. Metodologia stylu jest oparta na modyfikacji wzorca chaty góralskiej.

3. Pierwszym celem modyfikacji wzorca chaty góralskiej było uzyskanie funkcjonalnej komfortowej i higienicznej architektury, głównie o charakterze mieszkaniowym. Dalekosiężnym celem była kreacja stylu zakopiańskiego jako polskiego stylu narodowego.

4. Dążenie do stworzenia komfortowej i higienicznej architektury spowodowało konieczność powiększenia kubatury budynków w porównaniu z gabarytami wzorca chaty góralskiej. Powiększenie uzyskano głównie poprzez:

a. transformację dachu: wprowadzenie werand, werand oszklonych, tzw. pajt, wyględów oraz przyłapów; 
b. wprowadzenie wysokiej kondygnacji przyziemia obudowanej podmurówką z kamienia łamanego bądź otoczaków.

5. Materiałem stosowanym w budowlach stylu zakopiańskiego było przede wszystkim drewno i kamień używany w konstrukcji podmurówek. W dojrzałej fazie stylu zakopiańskiego stosowano również konstrukcje murowane.

6. W metodologii stylu zakopiańskiego elementy racjonalne przeplatały się z elementami swoistej mitologii. Było to zjawisko typowe dla stylów narodowych.

7. Architektura nasycona była zdobnictwem - ornamentyką, głównie o tematyce roślinnej. Według Witkiewicza zdobnictwo podkreślało cechy konstrukcyjne architektury.

\section{PRZYPISY}

1 S. Witkiewicz, Na przełęczy. Wrażenia i obrazy z Tatr, Gebethner i Wolff, Warszawa 1891, s. 39.

2 Tamże, s. 17-18.

3 Tamże, s. 21-22.

4 S. Witkiewicz, Wybór pism estetycznych, Towarzystwo Autorów i Wydawców Prac Naukowych Universitas, Kraków 2009, s. 313.

5 Tamże, s. 292.

6 Tamże, s. 300.

7 Tamże.

8 Tamże, s. 292-293.

9 Tamże, s. 301-302.

10 Tamże, s. 286.

11 Nowa Encyklopedia Powszechna PWN, t. 5, Wydawnictwo Naukowe PWN, Warszawa 1996, s. 935.

12 Witkiewicz, Wybór pism..., dz. cyt., s. 287.

\section{BIBLIOGRAFIA}

Bořutová D., Černoušková D., Kopecká M., Lehmannová M., Matuliková Z., Václavik R., Všetečka P., Dušan Jurkovič. The Architect and his House, red. M. Lehmannová, Moravian Gallery, Brno 2010.

Jabłońska T., Moździerz Z., „Koliba” Pierwszy dom w stylu zakopiańskim, Muzeum Tatrzańskie im. dra Tytusa Chałubińskiego, Zakopane 1994.

Matlakowski W., Budownictwo ludowe na Podhalu, Akademia Umiejętności, Kraków 1892.

Moździerz Z., Dom „Pod Jedlami” Pawlikowskich, Muzeum Tatrzańskie im. dra Tytusa Chałubińskiego, Zakopane 2003. 
Nowa Encyklopedia Powszechna PWN, t. 5, Wydawnictwo Naukowe PWN, Warszawa 1996. Tondos B., Styl zakopiański i zakopiańszczyzna, Zakład Narodowy im. Ossolińskich, Wrocław 2009. Radzikowski S.E., Styl zakopiański, Towarzystwo Wydawnicze we Lwowie, Kraków 1901. Witkiewicz S., Na przełęczy. Wrażenia i obrazy z Tatr, Gebethner i Wolff, Warszawa 1891. Witkiewicz S., Wybór pism estetycznych, Towarzystwo Autorów i Wydawców Prac Naukowych Universitas, Kraków 2009. styles Stanisław Witkiewicz's Zakopane style and its differentia specifica, Technical Transactions, vol. 12/2019, 53-62. DOI: 10.4467/ 2353737XCT.19.123.11448

ADRES BIBLIOGRAFICZNY ARTYKUŁU: Kwiatkowski K., Styl zakopiański Stanisława Witkiewicza i jego differentia specifica, Przestrzeń/ Urbanistyka/Architektura, 1/2020, s. 57-66.

DATA AKCEPTACJI OSTATECZNEJ WERSII DO OPUBLIKOWANIA: 13.02.2020. 